\title{
The Irresistible Rise of Asian Cinema 3
}

\author{
By Yvonne Ng \\ Spring 1994 Issue of KINEMA
}

\section{TIAN ZHUANGZHUANG: A DIRECTOR FOR THE 21st CENTURY}

Nowadays, when one speaks of mainland Chinese cinema, the names of directors Chen Kaige (Yellow Earth, Farewell, My Concubine) and Zhang Yimou (Red Sorghum, The Story of Qiu Ju) come easily to mind. Yet there are other fine directors in the country who are less well known but no less outstanding. One of them is Tian Zhuangzhuang, a contemporary of both Chen and Zhang.

Born in 1952 in Beijing, Tian comes from a family of film personalities; his father Tian Fang and his mother Yu Lan, both communist cadres, were well-known actors before the Cultural Revolution (1966-1976). Tian Fang, now deceased, was the first head of the Beijing Film Studio while Yu Lan is still in charge of the Children's Film Studio in Beijing. Tian Zhuangzhuang was just fourteen when the Cultural Revolution broke out. Two years later he was sent to the countryside in northern Jilin Province to be "re-educated" by the peasantry. He escaped the fields by joining the People's Liberation Army and returned to civilian life by securing an apprenticeship as cinematographer at the Beijing Agricultural Film Studio. There, he discovered his vocation: "When I first handled a movie camera, I felt so excited that my body shook, and I had a strange sensation, a feeling that this was something I wanted to do all my life."(1)

In 1978, he passed rigorous examinations to gain entry into the Beijing Film Academy which had just reopened after having been shut down during the Cultural Revolution. As Tian was past the age for new entrants in the cinematography department (which had a maximum age limit of 23 for newcomers), Tian studied directing instead. His classmates included Chen Kaige, Zhang Yimou, Wu Ziniu (Secret Decree, 1984; The Dove Tree, 1985), Zhang Junzhao (One and Eight, 1984) and Hu Mei (Army Nurse, 1985; Far from War 1987). They all graduated in 1982, becoming the first group of students to do so after the reopening of the Beijing Film Academy. Members of this class are now widely known as the Fifth Generation, so called because they are the fifth distinct group of filmmakers to have surfaced in mainland China. ${ }^{(2)}$

Fifth Generation films are characterized by their emphasis on cinematic qualities, unlike traditional Chinese cinema which attaches prime importance to plot, melodrama and literary adaptations. Fifth Generation filmmakers also rely on literary sources but melodrama is rejected in favour of formal innovation and experimentation. As opposed to the convenience of the Hollywood narrative model long accepted in China, the films of the Fifth Generation are generally slower-paced and are marked by still imagery, minimal dialogue and action. These characteristics often produce ambiguity of meaning aimed at encouraging audience reflection. They also provide a deeper and more complex worldview in which the traditional concepts of right and wrong are questioned. ${ }^{(3)}$

Among the 1982 graduates, Chen Kaige, Zhang Yimou and Tian Zhuangzhuang have become major representatives of Fifth Generation films, especially in the western world. While Chen and Zhang have already achieved international fame, most recently through Chen's 1993 Golden Palm winner in Cannes, Farewell, My Concubine (1992) and Zhang's The Story of Qiu Ju (1992) which won the 1992 Golden Lion in Venice, Tian is barely known in the international community of film critics and practically unheard of outside it.

While at the Beijing Film Academy, Tian distinguished himself in a video called Our corner (1980) which he co-directed with fellow-students Xie Xiaojing and Cui Xiaoqin. The film, about a young girl and a group of handicapped men, was noted for its sophisticated realism and minimal dialogue at a time when Chinese cinema had just begun to move away from traditional literary conventions. Tian also collaborated with Zhang Jianya and Xie Xiaojing to make the Fifth Generation's first professional feature which was actually a children's film called The Red Elephant (1983) for the Children's Film Studio in Beijing. The film, a fairy-tale about people of a national minority in south-west China, was commissioned and financed by Tian's mother Yu Lan. Tian then directed a film for television called A Summer Experience (1983) followed by a feature for the Kunming studio titled September (1984), a character study of a middle-aged woman. 
But it was his next two films that established Tian's importance abroad as a major filmmaker and which earned him a notorious reputation at home for making films that the mass audience could not comprehend. The first was On the Hunting Ground (1985) which Tian made at the invitation of the Inner Mongolia Film Studio. After living for a month with the Mongolians on the grasslands in preparation for the film, he drastically changed the script given to him by the studio. The original story centered around the themes of male dominance and jealousy with a complicated plot; in Tian's film, the narrative element practically disappears. Insofar as a narrative centre exists, it deals with a hunter's transgression of the Mongolian hunting code (laid down by Genghis Khan in the thirteenth century) and his subsequent penance.

Using local herdsmen rather than professional actors, the film is a semi-documentary which captures the hunting rituals, rhythms and patterns of daily life in a Mongolian tribe. In the film, juxtapositions of peace and violence, life and death, man and animal reflect the contradictions in Mongolian society. Above all, it reveals the all-encompassing force of the law which is not only applied in hunting but in structuring every sphere of Mongolian life -- morally, socially and economically. Tian reported that upon viewing the rushes, the Mongolian cast remarked how life on the grassland was really like that in the footage. The authorities at the Mongolia Film Studio, however, were not so pleased with the film pointing out that the Mongolian people are portrayed as very poor.

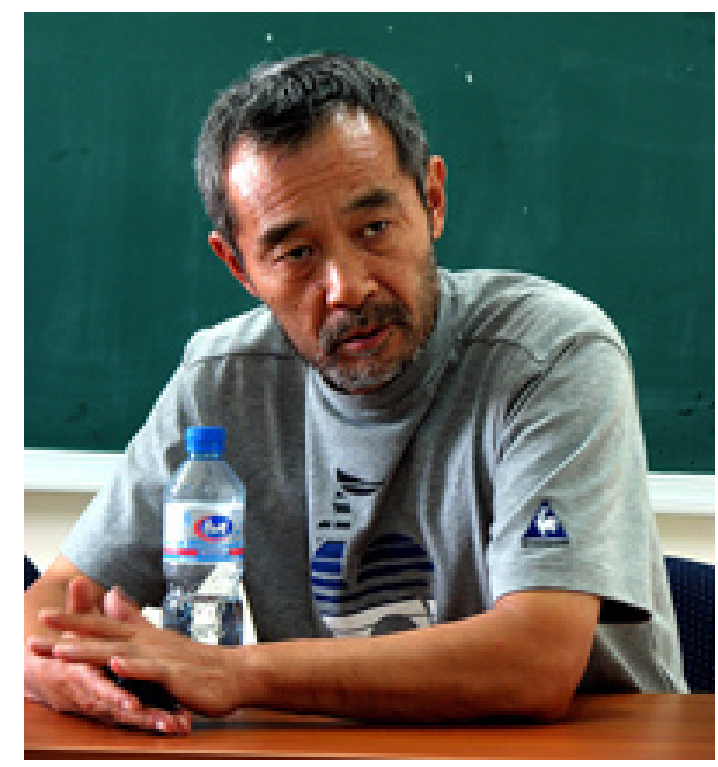

Figure 1: Director Tian Zhuangzhuang

Tian's next feature, Horse Thief (1986) explores the relationship between religion and humans in Tibetan society. Using a fragmented narrative and minimal dialogue, the film deals with the conflict between a Tibetan tribesman, Norbu, who steals horses for a living and his religion. Religion is the controlling force of life in Tibetan society and although Norbu is a thief, he is also a devout Buddhist. His relatively quiet life comes to an end one day when he steals a gift from the government to the monastery, a crime for which he and his family are ostracized and expelled from the tribe. Soon afterwards, Norbu's son dies and his death is interpreted as punishment from God. Although destitute, Norbu gives up his profession. He and his wife become nomads and their wanderings bring them to many major Tibetan festivals.

The power of the film (shot in Cinemascope) lies in Tian's pictorial composition, especially that of the rugged Tibetan landscape, in the unusual and inspired camera angles and in the effective use of tracking shots and superimpositions. Throughout the film, sound, light and colour are applied with a rare force to create images of transcendent beauty that transforms the cinematic experience into a spiritual one. In one hypnotic shot after another, Tian's documentary eye captures the solemnity and dignity of the Tibetan Buddhist ceremonies which are at once lyrical and surreal. These include the celestial burial in which human corpses are dismembered and laid out for the vultures to pick in the belief that when the birds fly skyward, 
the deceased will reach heaven more quickly; the worship of the mountain god; and the exorcism of the devil to rid the Tibetan countryside of a plague.

Both On the Hunting Ground and Horse Thief were not well-received by the Beijing authorities. Not only did the films, with their portrayal of strange customs, minimal plot and dialogue, alienate the Chinese officials, ordinary audiences and even some critics, but they also unmasked Beijing's official propaganda of the country's national minorities as rapidly prospering and modernizing. It took Horse Thief eight months to pass the censors before it was allowed limited release in China. By then, the two celestial burial sequences were trimmed, and the year 1923 was imposed at the start of the film, way before the People's Liberation Army marched into Tibet in 1950. The arbitrary year was convenient in explaining both the absence of Han Chinese characters in the plot, and the primitivism and poverty of the region, contrary to Tian's intention to make the film timeless.

Due to their "avant-garde" techniques and documentary realism, both On the Hunting Ground and Horse Thief were deemed unsuitable for foreign distribution. On the Hunting Ground owes its screening at the 1986 Pesaro Film Festival to the interest and help of Shanghai's Exploration Cinema House, an enlightened movie theatre that frequently exhibits films which are disregarded elsewhere in China. Tian had earlier tried together with Zhang Yimou to show both On the Hunting Ground and Yellow Earth at the 1984 Cannes Film Festival but as the films were on videotapes, they were not even looked at. When the Horse Thief finally appeared at the Rotterdam Film Festival in 1987 the original Tibetan dialogue (with Mandarin subtitles) had been dubbed into Mandarin with English subtitles. While it is a great privilege to be able to see the film, it is also a little odd to hear the tribal Tibetans articulating perfect Beijing Mandarin. For unspecified reasons, the film was subsequently withdrawn again from foreign distribution. ${ }^{(4)}$

On the mainland, while the average Chinese movie sells about a hundred prints for distribution, On the Hunting Ground sold only two; they were not distributed but went to the China Film Corporation for reference purposes only. Horse Thief performed marginally better, selling a total of seven prints. ${ }^{(5)}$ Yet the themes, styles and social functions of the two films have been debated and discussed by more people in China than those who have seen them.

Although On the Hunting Ground and Horse Thief focus on China's ethnic minorities, they also force their primary audience, the Han Chinese, to reflect upon their own situation. Like the Mongolians and Tibetans whose lives are entirely controlled by the hunting code and religion respectively, so the Chinese have a propensity to quietly submit themselves to control by the Communist state.

Tian's notoriety grew when in a September 1986 interview with Popular Cinema, China's most widely-read magazine, he countered the reporter's remark on the unpopularity of Horse Thief by saying he had made it for audiences of the next century -- to which a film bureaucrat replied that Tian could wait until then to pick up his salary.

In the next four or five years that followed, Tian managed to keep his head above water by making films that the studios were willing to invest in. Folk Artists (1987) is a literary adaptation about the folk singers and artists who settled in south-west China after fleeing the Japanese during the war of resistance. Rock $N^{\prime}$ Roll Youth (1988) is a breakdance musical while his 1990 Illegal Lives, a.k.a Special Surgery Room, remains unreleased. His next feature, Li Lianying, the Imperial Eunuch (1991) won a Special Mention at the 1991 Berlin Film Festival. Tian's latest film, The Blue Kite (Lan Fengzheng, 1993) reconfirmed him as one of China's great directors, when it was shown in Cannes last year. The film also won the Grand Prize at the 1993 Tokyo Film Festival despite a walkout by the Chinese delegation who complained that the film had not yet been authorized by the Beijing authorities.

A family saga and a coming-of-age story, The Blue Kite is set against the political repression and turmoil of Beijing during the years 1953-1967. It is to date Tian's most personal film, based on his own memories and those of his family and friends. The making of the film, a coproduction between Hong Kong's Longwick Film Production and the Beijing Film Studio, was a trial in itself, starting with the rejection of the first script by the film studio for political reasons. When the rough cut of the revised script was previewed by the Beijing film authorities in 1992, they promptly forbade the work print of the film to be shipped to Japan where post-production had been scheduled to take place. Finally, almost a year later, the Netherlands-based 


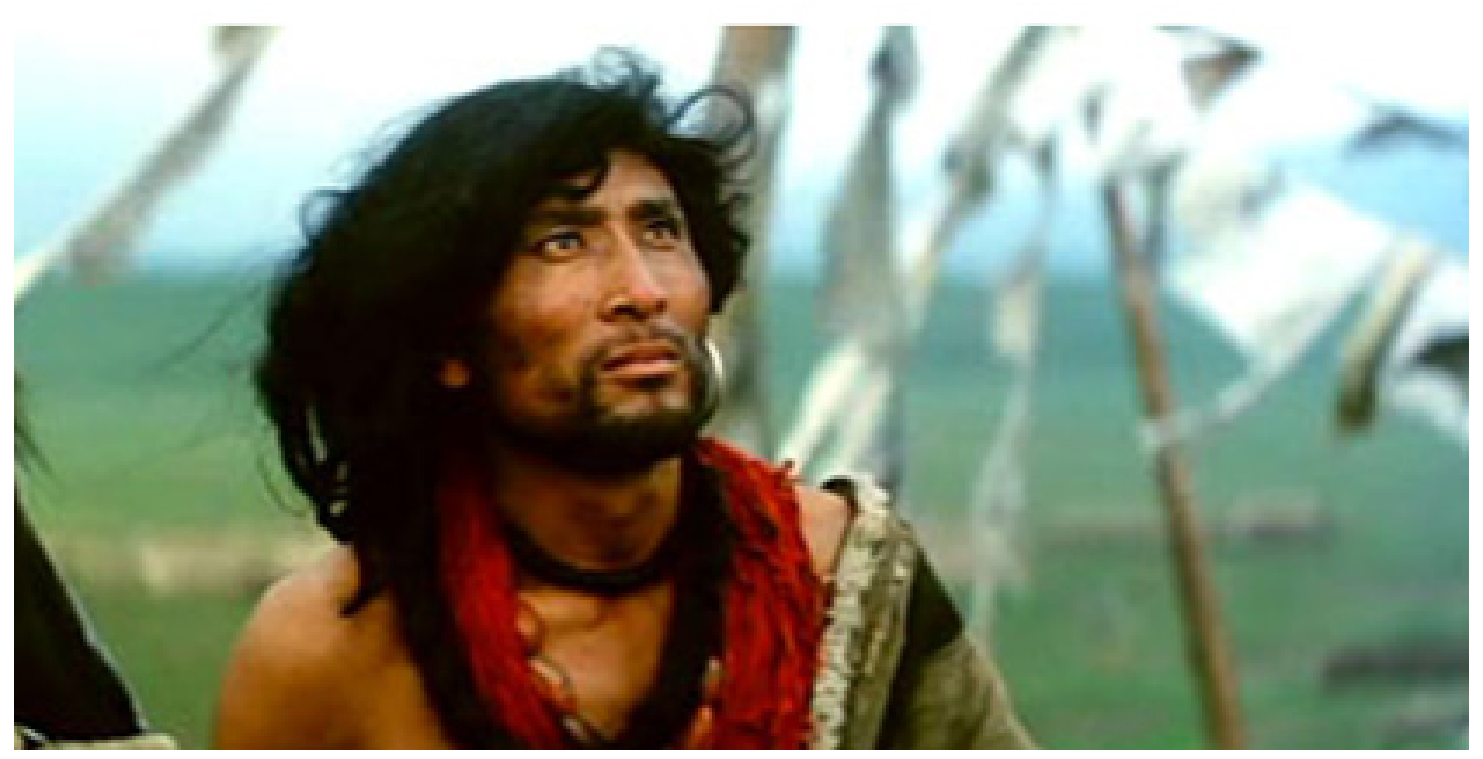

Figure 2: The Horse Thief (dir. Tian Zhuangzhuang, 1986)

Fortissimo Film Sales acquired world rights to the film and the post-production was completed according to Tian's script and detailed production notes without the director's presence.

Although for a long time Tian was overshadowed by the success of his contemporaries, Chen and Zhang, The Blue Kite should hopefully restore him to his rightful place beside them in the international spotlight. However, Tian himself does not seem interested in seeking publicity. In an interview with Asian cinema specialist, Peggy Chiao, he explains his decision to make The Blue Kite, "something with a bit of meaning", despite knowing that it would bring many difficulties. "I knew that were I to make the film I wanted to make, it wouldn't be a happy project for either me or the people who have the responsibility for passing it, and I'd end up in a heap of trouble. I don't like becoming a news item, but I felt that if I didn't make this film, I just couldn't rid myself of this obsession."

Tian Zhuangzhuang is not only one of China's greatest directorial talents, he is also one of the most independent-minded. Long before it was fashionable for artists and intellectuals to be involved in prodemocracy movements, Tian was the only member of the film community and one of thirty-three people who signed an open letter in 1989 calling for the release of political prisoners. He seems to be someone who will continue to act according to his conscience. He has a refreshingly, not to mention courageously, relaxed attitude regarding the Communist Party's hostility to his films, observing that the Constitution provides for a sense of proportion: "I don't kill, commit arson, raping or go whoring, so they can't arrest me."(6)

Most admirable, perhaps, is Tian's commitment to filmmaking. He has said that even if his films were to suffer the fate of Van Gogh's paintings, that is, be recognized only after the artist has died, he cannot stop making films. The recent recognition, at least in the West, of this artist's significance gives hope that Tian Zhuangzhuang will not have to suffer Van Gogh's fate.

\section{Notes}

1. From an interview conducted by George S. Semsel and interpreted by Ma Ning in the spring of 1984. In Chinese Film: The State of the art in the People's Republic, ed. George Stephen Semsel (New York: Praeger, 1987), p. 129.

2. The division of mainland Chinese filmmakers into generations is discussed in more detail in David A. Cook's A History of Narrative Film, 2nd ed. (New York: Norton, 1990), p. 818 and in John A. Lent's The 


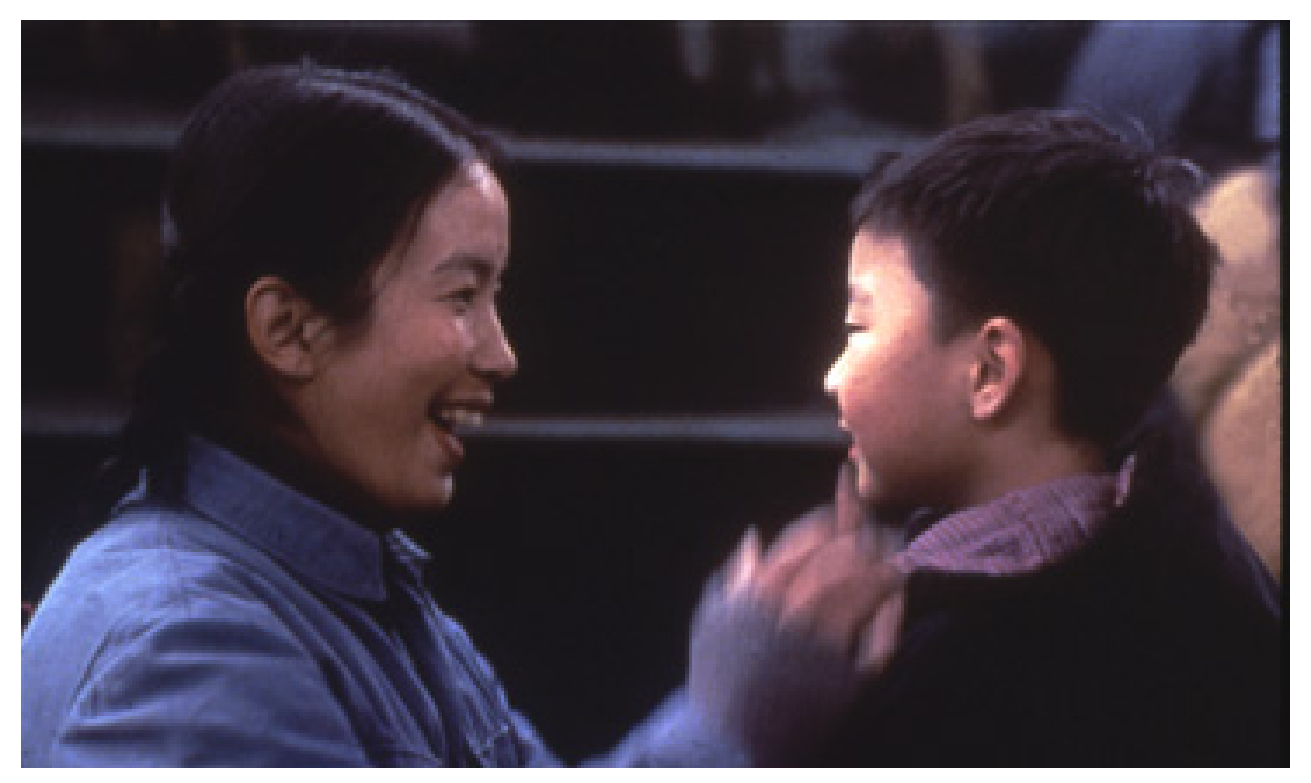

Figure 3: The Blue Kite (dir. Tian Zhuangzhuang, 1993)

Asian Film Industry (London: Christopher Helm Ltd, 1990), p. 20.

3. Chen Kaige and Tony Rayns, King of the Children $\&$ the New Chinese Cinema (London: Faber \& Faber, 1989), p. 54.

4. Horse Thief was also available for sale on LaserDisc in North America. In 1993, however, it was deleted from retail for undisclosed reasons.

5. Chris Berry, "Market Forces: China's 'Fifth Generation' Faces the Bottom Line," in Perspectives on Chinese Cinema, ed. Chris Berry (London: British Film Institute, 1991), p. 118.

6. Tian Zhuangzhuang, interview with Peggy Chiao, Imagemaker, No. 32, Sept. 1992.

\section{Author Information}

Yvonne NG is the co-author of Latent Images: Film in Singapore Second edition (NUS Press, 2010); Latent Images: Film in Singapore (OUP, 2000) and Latent Images: Film in Singapore CD-ROM (Singapore, 2003). She has written on Singapore and Asian cinema and contributes to the International Film Guide. 